\title{
Many Names Without A Face. Satan And Demonic Beings In Early Christian Literature (Acta Synodalia)
}

\author{
Michal Ludewicz \\ The John Paul II Catholic University of Lublin/ Faculty of theology
}

\begin{abstract}
The aim of my poster is to describe, how was Satan (or the Devil) and other demonic beings, percived by early medieval Christians. To demontrate this, the acts of synodes (known as Acta Synodalia) from 3 th to 6 th will be put under examination. From the lecture of the synodical acts it becomes clear that Satan was hardly ever the main object of christian atention, nevertheless bishops gathered on synods were aware of his existence and malignous actions. In the synodical acts the archenemy of the faithful is mentioned under many names: i.a. Satanas, Diabolus, Antichristus, Daemon, superbiae inventor et princeps (inventor and leader of pride), humanae salutis et veritatis inimicus (the enemy of human salvation and truth), but there are only few explicit statements about his personality. Mostly Satan and other demonic beings are mentioned as those who were responsible for inspiring humans to commit sins like adultery or suicide. Devil himself was also considered as the main fount of heresies and schism within the church. He introduced unrest and turmoil to the community of faithful. For many Christians the evil actions of Antichrist were a clear sign that the world was coming to its end.
\end{abstract}

Keywords: Demons; Devil; heresies; imagination; Synodes 